MICHALA LÔNČÍKOVÁ

\section{The End of War, the End of Persecution? Post-World War II Collective Anti-Jewish Violence in Slovakia}


MICHALA LÔNČÍKOVÁ

FACULTY OF ARTS, COMENIUS UNIVERSITY IN BRATISLAVA

UDC 341.485“1945" $(=411.16)(470)$

343.226 "1945“(=411.16)(470)

https://doi.org/10.32728/flux.2019.1.8

Original scientific paper

\section{The End of War, the End of Persecution? Post-World War II Collective Anti-Jewish Violence in Slovakia ${ }^{1}$}

Contrary to the previous political regime of the Slovak state (1939-1945), official policy had significantly changed in the renewed Czechoslovakia after the end of World War II, but anti-Jewish sentiments and even their brachial demonstrations somewhat framed the everyday reality of Jewish survivors who were returning to their homes from liberated concentration camps or hiding places. Their attempts to reintegrate into the society where they had used to live regularly came across intolerance, hatred and social exclusion, further strengthened by classical anti-Semitic stereotypes and prejudices. Desired capitulation of Nazi Germany and its satellites resulted also in the end of systematic Jewish extermination, but it did not automatically lead to a peaceful everyday life. This paper focuses on the social dynamics between Slovak majority society and the decimated Jewish minority in the first postWorld War Il years and analyses some crucial factors, particular motivations and circumstances of the selected acts of collective anti-Jewish violence in Slovakia. Moreover, the typological diversity of the specific collective atrocities will be discussed.

\section{KEYWORDS}

collective violence, Jews, pogrom, Slovakia, Topoľčany

1 The research for this article was supported by grant no. 16-01775Y, "Inclusion of the Jewish Population into Postwar Czechoslovak and Polish Societies", funded by the Czech Science Foundation. 
Common Monday morning in the city of Topoľčany started as usual - marketers were preparing their goods and crafts for selling, women were thinking about what they needed to buy for their households and for cooking, men went to work or service, children left to school. ${ }^{2}$ At first sight, another normal week had begun, nothing unusual seemed to be happening. There was just a group of some 60 women who gathered in the city centre and were on their way to the District National Office (ONV) where they wanted to ask the deputy of ONV whether the news about the planned nationalization of schools and the replacement of Catholic nuns in the local people's school by Jewish teachers was true. Even though, the deputy and the school inspector denied this information, the crowd was growing and chanting hateful antiJewish slogans while marching towards the school where a Jewish doctor was vaccinating children by allegedly poisonous injections. According to rumours, which were spread among the people, one of them should have been already dead. Violent entrance into the school building resulted in a physical attack on the accused doctor who was trying to run out of the hands of the attacking mob, looking for help and protection outside the building. Although the police station was located hardly a hundred meters from the school building, doctor Berger was severely injured in the very centre of the city in the morning. This "episode" became a detonator for mass hysteria and violence in the streets. The local station of National Security ${ }^{3}$ did not undertake any appropriate activity to dispense the crowd in the beginning and the following events went completely out of their hands. Members of the National Security were not able to calm down the situation and secure order in the city, so a military unit was called to assist. Some of the soldiers, who had originally come to protect the victims, joined the violent crowd. ${ }^{4}$ This several-hour-long pogrom affected 47 Jews, including some children and elderly people, fifteen of whom required medical treatment in a hospital. ${ }^{5}$

Outlined scenes from Topoľčny could be appropriately matched to the period of World War II and the persecution of the Jewish community which was organised, legalised and also accelerated by the political representatives of the Slovak state, which remained a faithful Nazi Ally until the bitter end of the Third Reich in May 1945. But in fact, the Topolčany pogrom occurred on September 24, 1945 - more than five months after the liberation of Slovak territory, where the outbreak of pogroms in general was neither a typical nor frequent phenomenon even under the previous political regime. ${ }^{6}$ From this perspective, it is rather questionable and maybe slightly disturbing that such a large act of collective anti-Jewish violence, committed by the local citizens, happened after the Holocaust. On the other

2 Unless otherwise indicated, the information to the events in Topoľcany come from the dossier - Slovenský národný archív (SNA), f. Povereníctvo vnútra - prezídium (PV-prez.), box 2, 2087/46-prez.

3 Official name for standard, not any secret or intelligence service, police forces in Czechoslovakia after 1945.

4 SNA, f. PV-prez., box 2, 2087/46-prez.

5 Jana Šišjaková, "'Prípad Topoľčany' - Protižidovský pogrom (nielen) z pohladu dobových dokumentov," Acta historica Neosoliensia 10 (2007): 232-240.

6 Robert Büchler, Židovská náboženská obec v Topolčanoch (Bratislava: Slovenské národné múzeum - Múzeum židovskej kultúry, 1996), 109. 
hand, taking into account the situation in neighbouring countries, the Kielce pogrom in Poland ${ }^{7}$ or the Kunmadaras pogrom in Hungary, to name but a few, ${ }^{8}$ it is evident that the events in Topolčany were not exceptional in the Central and Eastern European environment in early post-war years.

\section{Jews and Gentiles: A Pre-Story}

In order to analyse (trying to understand would be too great an ambition) the acts of collective anti-Jewish violence in the aftermath of the Holocaust in Slovakia, it is necessary to contextualise, at least briefly, the general situation in the country and to emphasise the crucial and symptomatic factors which framed Jewish and Gentile relationships and also their social dynamics.

First of all, it has to be stated that anti-Semitism in Slovak majority society was more deeply rooted. It was not a product of the $20^{\text {th }}$ century, nor was it a Nazi ideological indoctrination. Religiously defined anti-Judaism was being spread in the traditionally Christian, dominantly Catholic, society since the Middle Ages and regularly caused various conflicts and segregation. Position and status of Jewish community in the Hungarian part of the Habsburg Monarchy had significantly changed in the second half of the $19^{\text {th }}$ century when Jews became emancipated and received civil rights. ${ }^{9}$ Modern anti-Semitism gradually became a new paradigm in this discourse. Moreover, the whole society was facing the upcoming process of modernisation, which opened new possibilities for emancipated Jews who were more capable of adapting to new conditions, which often resulted in their rapid social and economic boost. Consequently, this development resulted in the strengthening of popular feelings of threat and increasing xenophobia in society. ${ }^{10}$ Later, a continual process of secularisation, liberation and the forming of modern Jewish nationalism" - Zionism represented those factors which led into broader diversity of the originally religiously defined community. The collapse of the monarchy and further establishment of the First Czechoslovak Republic, which was based on democratic principles, was not completely free from anti-Semitism. ${ }^{12}$ For example, there were attempts to limit Jewish businesses and the Ministry of Plenipotentiary for Slovakia revised regulations of Jewish business licenses..$^{13}$

Even though the Jewish community didn't represent a solid or unified group since it had gone through dramatical changes in the second

7 Jan T. Gross, Fear: Anti-Semitism in Poland After Auschwitz (New York: Random House, 2007).

8 Péter Apor, "The Lost Deportations and the Lost People of Kunmadaras: A Pogrom in Hungary, 1946," Hungarian Historical Review 2, no. 3 (2013): 566-604; Brigitte Mihok, "Judenfeindliche Ausschreitungen in Ungarn Zur Dramaturgie eines Pogroms: Kunmadaras 1946," in "Juden unerwünscht" Anfeindungen und Ausschreitungen nach dem Holocaust, eds. Wolfgang Benz and Brigitte Mihok (Berlin: Metropol, 2016), 163-176.

9 Petra Rybářová, Antisemitizmus v Uhorsku v 80. rokoch 19. storočia (Bratislava: Spoločnosť Pro Historia, 2010), 31.

11 There was a possibility to proclaim a Jewish nationality in the First Czechoslovak Republic.

12 Michal Frankl and Miloslav Szabó, Budováni státu bez antisemitizmu? Násilí, diskurz lojality a vznik Československa (Prague: Nakladatelství Lidové noviny, 2016).

13 Miloslav Szabó, Od slov k činom: Slovenské národné hnutie a antisemitizmus 1875 - 1922 (Bratislava: Kalligram, 2014), 206-219. 
half of the $19^{\text {th }}$ century, the perception of Jewishness and their "otherness" in mostly conservative, rural and religious Slovak society was still dominantly determined by confessional criteria, even on the eve of World War II. In line with the above mentioned, the story of this inter-group tension was evidently longer than the limited existence of the Slovak state(1939-1945). On the other hand, something substantial had changed precisely in this approximately sixyear-long period - anti-Semitism became a political doctrine and one of the inner-political pillars. ${ }^{14}$ Single-ruling Hlinka Slovak People's Party (Hlinkova slovenská ľudová strana, HSĽS) did not invent anti-Semitism, it only cleverly misused and utilised existing prejudices and negative attitudes towards the Jews. ${ }^{15}$ During the regime of HSĽS, Jewish community was discriminated and persecuted by its own state; a continual process of their pauperisation and even further deportations to Nazi concentration camps in $1942^{16}$ were legalised and authorised by the main political representatives. ${ }^{17}$ Perception of the Jew as a mythological eternal enemy, which was highly supported by the state-controlled propaganda and the process of "Aryanisation" of Jewish property, turned a large number of ordinary people into co-perpetrators. ${ }^{18}$ Events of the Holocaust have consequently and essentially re-shaped Jewish and Gentile relationships in Slovakia.

\section{Post-War Everyday Reality}

Although the states' approach towards the Jewish community did a 180 -degree turn in the renewed Czechoslovak republic - Slovak National Council (SNR), the highest political body in Slovakia at that time, abolished the validity of racial legislation via Regulation no. 1/1944 Sb. n. SNR ${ }^{19}$ and ended the era of political anti-Semitism - hostile mood among the public did not automatically vanish. Despite international acceptance of the legal continuity of Czechoslovakia, the two parts of the country had a different historical and political experience during the war period. On the one hand, the Protectorate of Bohemia and Moravia became part of the Third Reich, while on the other, there was the heritage of the satellite Slovak state which existed under the umbrella of the Nazis. This dichotomy also impacted the immediate post-World War II development in the country where the resistance

14 First anti-Semitic measures were discussed and proposed by HSĽS even before foundation of the Slovak state during the period of the Slovak autonomy (October 6, 1938 - March 14, 1939).

15 Ivan Kamenec, "Trauma holokaustu. Historický alebo morálny problém?" in Slovenská otázka dnes: výber textov z časopisu OS 1997- 2006, ed. László Szigeti (Bratislava: Kalligram, 2007), 208.

16 In contrary to the $2^{\text {nd }}$ wave of deportations in 1944 which were organized and realized by the Nazi occupying forces with the assistance of paramilitary Hlinka Guard forces - PO HG.

17 Herbert C. Kelman, "Violence without Moral Restraint: Reflections on Dehumanization of Victims and Victimizers," Journal of Social Issues 29, no. 4 (1973): 25-61.

18 Michala Lônčíková, "Was the antisemitic propaganda a catalyst for tensions in the SlovakJewish relations?" in Jews and Gentiles in Central and Eastern Central Europe during the Holocaust. History and Memory, eds. Hana Kubátová and Jan Lániček (London: Routledge, 2018), 76-98.

19 This regulation was originally enacted by the SNR during the Slovak National Uprising in autumn 1944 and came back to power after the resumption of the Czechoslovak Republic. 
$S_{N R}^{20}$ remained in power after the renewal of the Republic. Diverse political development can be partially exemplified by the juridical system - f. e. special People's Courts, established analogically to other European countries, to judge former collaborators, traitors and occupiers were run and organised on a different legal basis in Czech territory and in Slovakia. ${ }^{21}$ Therefore, exclusive focus on the Slovak part does not follow any nationalistic criteria, but refers to a specific administrative unit of the Republic.

Situation in the first post-war years was highly influenced by problematic economic and social conditions, frustration and disappointment in the society. Various parts of the country faced military operations, ${ }^{22}$ the most heavily damaged was the region of Eastern Slovakia where, according to the official UNRRA (United Nations Relief and Rehabilitation Administration) report, the situation was still critical even in January $1946 .{ }^{23}$ Everyday life was eminently determined by a struggle to satisfy basic needs - nutrition supplies and medical care were insufficient, unemployment rate was rising, infrastructure was destroyed, etc. Even though the unsatisfactory social and economic situation was not the only factor that escalated tensions among the people, it created an "ideal" environment for finding scapegoats, people and institutions allegedly responsible for the alarming circumstances. On the one hand, the central government was blamed for their lack of interest in the restoration of the peripheries in public discourse ${ }^{24}$ and on the other, it was not the first time that frustration turned against minorities. Regular reports of the National Security informed about the situation in various parts of the country; majority-minority tensions appeared, for example, in one Eastern Slovak city of Michalovce:

\begin{abstract}
The citizens of Slovak nationality along with the citizens of Ruthenian nationality live in great harmony. This, however, is not the case with the Jewish minority. One can see mutual distrust and even hatred. Citizens of the Jewish religion condescend upon their fellow citizens, they always pursue benefits and demand to be first everywhere. They have failed to participate in the construction works so far. The rest of the population sees this and openly criticises it. And their criticism is justifiable. While the citizens of the Jewish religion have obtained nearly the same socioeconomic status as before the war, the rest of the population suffers from poverty and deprivation. ${ }^{25}$
\end{abstract}

This information must be analysed due to limitations of this type of source and it needs to be understood as a specific case. However, it addresses a rather interesting diversity in the perception of two minorities - Ruthenians and Jews - where Jews should have played a controversial role. This report

20

21

It was originally established during the Slovak National Uprising in September 1944.

Michala Lônčíková, "Holokaust pred súdom. Správy o deportáciách z okresu Banská Bystrica v povojnovom ľudovom súdnictve," in Slovensko a nacistické koncentračné tábory, eds. Eduard Nižňanský and Michala Lônčíková (Bratislava: Stimul, 2015), 58-63.

Ľudovít Hallon, Miroslav Sabol, and Anna Falisová, Vojnové škody a rekonštrukcia Slovenska 1944 - 1948. (Hospodárstvo, infraštruktúra, zdravotníctvo) (Bratislava: Historický ústav SAV, 2011), 20-77.

Archiv bezpečnostních složek (ABS), f. 302, 302-155-5.

Vojenský historický archív (VHA), f. Operace banderovci, box 50, 1/Taj. 1946.

Report from Humenné, January 5, 1946. In: SNA, f. Povereníctvo vnútra - bezpečnosť (PVbezp.), box 2, without no. 
contained a list of charges that Jews were often blamed for. Blaming them for rejecting manual work or for rapid socioeconomic progress after the war repeated the same refrain as in the late $19^{\text {th }}$ century. Traditional stereotypes were accompanied by alleged preferences in restoration of Jewish houses rather than those of Christians ${ }^{26}$ emphasising their involvement in smuggling and black-marketing, which was logically announced in the border area and not only exclusionary to the Jewish community, ${ }^{27}$ and supposedly unfair and unequal distribution of UNRRA supplies. ${ }^{28}$ The feeling of favouring Jews was even catalysed by help from JOINT (American Jewish Joint Distribution Committee). ${ }^{29}$

Another apple of discord and symptomatic determinant of Jewish and Gentile relationships in the Slovak environment was the former Jewish property, both immovable and moveable. In fact, the "Aryanisation" process, for which HSĽS was in charge, led to the creation of the Slovak middle class. ${ }^{30}$ Those members of society who were actively involved in this "state-organised and guaranteed robbery" were often not willing to give the property back to the Holocaust survivors. The legal path of restitution was not immediate as the adequate legal norm was adopted only in May 1946. ${ }^{31}$ Moreover, Jews were in a conflict of interest with aryanisers as well as former partisans who were expecting adequate compensation for their previous efforts. ${ }^{32}$ This situation indicated that the question of restitution was not a number one political preference because it did not represent a popular step among potential voters in the forthcoming elections, which were held in May 1946.

\section{Coming Back Home?}

Immediately after the end of the war, holocaust survivors were considered to be the same victims of World War II as other civilians. Even though only a third (approximately 25-30 thousand) of the former Jewish community in Slovakia came back from the concentration camps or survived in hiding, cynical voices claiming that more Jews were coming back than originally had left were gaining in strength. ${ }^{33}$ Euphoria from the end of the war and dreams of returning home soon encountered the harsh reality and attempts of reintegration into society, and starting a common life did not often proceed according to an idyllic scenario. ${ }^{34}$

26 Report - August 1946. In: SNA, f. PV-bezp., box 2, without no.

27 Report - November 1946. In: SNA, f. PV-bezp., box 2, without no.

28 Štátny archív v Košiciach, pracovisko Archív Trebišov, f. Okresný národný výbor v Trebišove 1945-1948 - prezidiálne spisy, box 21, 129/46 prez.

29 Štátny archív v Prešove (ŠAPO), f. Okresné veliteľstvo Národnej bezpečnosti(OV NB) Sabinov, box. 5, 163dôv./1945; ŠAPO, f. OV NB Sabinov, box 5, 209dôv./1945.

30 Eduard Nižňanský, Holokaust na Slovensku 7: Vzťah majority a židovskej minority (náčrt problému)(Bratislava and Zvolen: Nadacia Milana Šimečku and Klemo, 2005), 7.

31 Ivica Bumová, "Židovská komunita po roku 1945 snaha o občiansku a sociálnu rehabilitáciu," in Holokaust a ko historický a morálny problém v minulosti a v súčasnosti, ed. Monika Vrzgulová and Daniela Richterová (Bratislava: Úrad vlády Slovenskej republiky, 2008), 52-60.

32 Report from Humenné, September 6, 1946. In: SNA, f. PV-bezp., box 2, without no.

33 For example, testimonies of Alexander Bachnár (Available online: http://www.centropa.org/ biography/alexander-bachnar, accessed June 20, 2017) and Matilda Hrabovecká (Available online: http://www.centropa.org/biography/matilda-hrabovecka, accessed June 20, 2017). 
As I have already mentioned, social and economic factors cannot be taken as a single unambiguous explanation for anti-Semitic invectives or even violence. Jewish-Gentile everyday co-habitation, however decimated the Jewish community may have been, was still shaped by the same prejudices and conspiracy theories which partially impacted the patterns of behaviour of the Slovak majority. Rumours about blood libels took part in the public discourse also after World War II - there were several alleged attempts to kidnap Christian children and even put them into meat cans, ${ }^{35}$ or to use their blood for the corner stone in the "Jewish church" in their new homeland. ${ }^{36}$ Furthermore, the continuously handed superstitions of alleged Jewish attempts to annihilate Christians acquired real contours, f. e. in mobilising the crowd in the previously sketched out Topoľcany pogrom and also in Eastern Slovakia where the local National security dealt with cases of allegedly intentionally poisoned sweets, cigarettes and watermelons. Further investigation denied these allegations - rumours of skin rash after eating sweets could not be verified, since the mother of the supposedly sick child did not take him to the doctor, and stomach problems after eating a watermelon were caused by rapid water intake. ${ }^{37}$

Expressions of hostility and precise demonstrations that Jews are not welcome in Slovakia regularly appeared in the form of various leaflets or posters, anonyms and verbal invectives usually in the streets or in, at the time eminently male arena, the pubs. Swearing at Jews often served as a common topic for small-talk or it appeared in popular songs such as the British evergreen "It's a Long Way to Tipperary," with changed lyrics referring to the long way to Palestine. ${ }^{38}$

In many cases these invectives and "brave" proclamations faded away with alcohol or after a long sleep. On the other hand, in some situations the potential perpetrators really turned their words into actions. Members of Jewish communities also faced and experienced many forms of individual physical violence. Just to mention a particular incident, threats to a Jewish family in Spišské Hanušovce resulted in a serious bomb-attack on their house..$^{39}$

\section{Collective Violence - Spontaneous vs. Planned}

Immediate post-war severe economic and social conditions further accelerated the tension among the people. Everyday social reality was

\footnotetext{
World War II," in The Jews are Coming Back. The Return of the Jews to their Countries of Origin after WWII, ed. David Bankier (Jerusalem: Berghahn Books, 2005), 257-276; Dorota Tabitha Moravská, "Československo," in Návraty. Poválečná rekonstrukce židovských komunit v zemích středovýchodní, jihovýchodní a východní Evropy, eds. Kateřina Králová and Hana Kubátová (Prague: Univerzita Karlova v Praze, Nakladatelstvi Karolinum, 2016), 65-94; Michala Lônčíková, "Coming back home? Anti-Jewish Violence in Slovakia after the Holocaust," in "Juden unerwünscht," Anfeindungen und Auschreitungen nach dem Holocaust, eds. Wolfang Benz and Brigitte Mihok (Berlin: Metropol-Verlag, 2016), 191-212. SNA, f. Sdruženie rasovo prenasledovaných (SRP)[unworked], 2709/51.

ABS, f. 2M, 13372.

Report from Michalovce August 31, 1946. In: SNA, f. PV-bezp., box 2, without no.

38 ŠAKE, f. Štátne zastupitelstvo 1922-1949, box 52, Št 2758/47.

39 ŠAPO, špecializované pracovisko Archív Levoča, Štátne zastupitelstvo 1922-1949, box 284, Št 113/1946.
} 
somewhat framed by robberies, thefts, black-marketing, smuggling and increasing criminality. Lack of state power and real control over the country in the transition period created a suitable environment for outbursts of violence, in particular exclusionary riots, against minorities, including the Jewish one. ${ }^{40}$ Not every single attack committed against Jews must be necessarily recognised as an anti-Semitic act. In many cases social and human scientists are still reluctant to denote atrocities against Jews as primarily anti-Semitically motivated. Human life and patterns of behaviour are more comprehensive, however, and there is no doubt about the presence of anti-Semitism in the Slovak majority society. What we actually have are windows through which we can observe particular events. ${ }^{41}$ To overcome a simplified analysis of the motives and reasons for tension and even open demonstrations of violence, it is necessary to think outside of stereotyped boxes.

Coming back to a short prologue of this paper, the Topoľcany pogrom became the largest anti-Jewish collective violent act which had taken place in Slovakia in the post-war period. Actually, among more collective atrocities $^{42}$ only this one can be denoted as a pogrom according to the definition of Werner Bergmann. ${ }^{43}$ Naturally, there were more factors which mobilised and incited the crowd, and the Topolčany case had its context. Approximately 3000 Jews, predominantly Orthodox ones, lived in the city in the period of the Slovak state. Numerically, this constituted a third of the city's inhabitants and accounted for the majority of standard middle class with important positions in economic life, especially in business and trade..$^{44}$ Only about 550 of them survived. ${ }^{45}$

Even though the negative attitudes towards the survivors were evidently spread among the aryanisers, who were not willing to give their property to its former owners, considering the events on September 24, 1945, as their prepared agenda would be simplified and even incorrect - a pogrom as such is never organised. Outbursts of spontaneous crowd violence naturally always have their pre-story. Further culmination of tension and escalation of violence represents only the tip of the iceberg. A cobweb of various factors and events met together on that Monday morning in Topoľcany. The crowd of women that decided to protest against supposed replacement of nuns with Jewish teachers encountered more anti-Jewishly seasoned rumours about damaged Christian symbols and allegedly poisoned vaccination in the school building. The Monday in question was also a market day, so there were people

\footnotetext{
40 Werner Bergmann, "Exclusionary Riots: Some theoretical Considerations," in Exclusionary Violence. Antisemitic Riots in Modern German History, eds. Christhardt Hoffmann, Werner Bergmann, and Helmut Walter Smith (Michigan: University of Michigan Press, 2002), 163. See the novel by Wilder Thornton, The Bridge of San Louis Rey (New York 1986).

42 For example, anti-Jewish riot in Bratislava in August 1946. See Ivica Bumová, "Protižidovské výtržnosti v Bratislave v historickom kontexte (august 1946)," Pamät̆ národa 3 (2007): 14-29.

43 Werner Bergmann, "Pogroms," in International Handbook of Violence Research, eds. Wilhelm Heitmeyer and John Hagan (Dordrecht; Boston: Kluwer Academic Publishersm 2003), 359.

44 Andrea James, "Zmeny v postavení židovskej komunity v okrese Topoľčany počas obdobia slovenského štátu," in Česko-slovenská historická ročenka 6, ed. Vladimír Goněc (Brno: Masarykova univerzita v Brně a Česko-slovenská komise historiků roku, 2001), 125. 
gathered on the square and the crowd was rising rapidly. According to later investigation of the pogrom, their number was estimated to 160 . The scene at the school was saturated by more coincidences. It was true that doctor Berger was carrying out the compulsory vaccination of children, aged 7-8, against smallpox and some of the pupils were crying - as children their age do while being vaccinated. One of the nuns tried to protect Berger from the marching mob, so she locked the door. The detonator was set up, hoaxes about poisoned children roused the crowd into a psychical attack against the doctor, accompanied by hateful verbal invectives by one man in the crowd:

\begin{abstract}
We will not let you take our school; remove our nuns and we shall not let you set up a Jewish school. At this point a soldier standing nearby started to shout that he did not join the partisans for the Jews to be well off. ${ }^{46}$
\end{abstract}

Doctor Berger became the first victim of the pogrom. Mass hysteria that followed moved from the streets inside Jewish apartments where attacks and robberies continued. The pogrom lasted several hours.

Even though anti-Semitism was not a political doctrine anymore, state institutions were not strong enough and efficient in protecting the Jewish survivors from mass violence. A significant role was played also by individuals such as some of the soldiers who actively participated in the pogrom and afterwards received disciplinary punishment; one of them was accused of abuse and theft. ${ }^{47}$ Nonetheless, the Topoľčany pogrom surpassed the boundaries of the city, rumours of Jewish children killings drove the residents of a nearby village Žabokreky to the streets, too. ${ }^{48}$ Members of local National Security claimed that Jews were to blame themselves and left the insurgent crowd as they were.

Nine major pogrom participants were seized and placed in a detention camp in llava and further 45 criminal charges were subsequently filed. ${ }^{49}$ Despite the call of the political representatives for a quick investigation of the pogrom, ${ }^{50}$ the legal procedure was surprisingly slow and the trial of Anton B. and others stretched until the early 1950s. ${ }^{51}$

Another tragical act of collective anti-Jewish violence took place in Ulic and Kolbasov, two little villages in North-Eastern Slovakia, on the night of December 6/7, $1945 .{ }^{52}$ Contrary to the events in Topoľcany, this massacre, which claimed 15 murdered Jews, was planned and intentional. Security close to Polish and Ukrainian (USSR) borders was critical. Crossing the border was smooth and security was insufficient. National Security was blamed for being

46 SNA, f. PV-prez., box 2, 2087/46-prez.

47 Ivan Kamenec, "Protižidovský pogrom v Topoľčanoch v septembri 1945," Studia Historica Nitriensia 8 (2000): 93.

48 Pamätná zápisnica o udalostiach z 24. IX. 1945 v Topoľčanoch, ktoré boly zistené vyslanou komisiou. In: SNA, f. SRP, [unworked], without no.

49 Obžaloba pred Krajským súdom v Bratislave Št 1100/46. In: SNA, f. SRP [unworked], without no.

50 "Ze zápisu 62. schůze vlády o projevech antisemitizmu na Slovensku," in slovensko a Izrael v letech 1945 - 1956. Dokumenty, ed. Marie Bulínová (Brno: Ústav pro soudobé dějiny AV ČR ve spolupráci s Historickým ústavem České armády a se Státním ústředním archivem 1993), 17-27.

51 Štátny archív v Bratislave, f. Štátne zastupiteľstvo v Bratislave 1919 - 1949, 1100/1946.

52 Michal Šmigel, Banderovci na Slovensku(1945-1947)(Banská Bystrica: Univerzita Mateja Bela, 
passive, irresponsible, unreliable and it should have been adjusted by the Army forces. ${ }^{53}$ Moving of various troops, displaced persons and migrants was out of control of the state. Among those who were regularly entering the area of Slovakia were also Bandera's troops, members of the Ukrainian Insurgent Army (UPA). They were fighting for the free Ukraine and ideologically stood against Jews, but also Communists and Poles. During 1945 and 1946 Bandera's troops organised many propagational visits, in particular to Eastern Slovakia, in order to spread their political ideas. ${ }^{54}$ They were often in touch with the locals, their tactics were following the same pattern - they asked where the Jews and Communists lived and how many members the National Security and Financial Guard had. ${ }^{55}$

On a snowy December night, intentional and planned murder of Jewish survivors in Ulič and Kolbasov was committed. At both places, unknown armed troops occupied the local National Security station, stole the supplies and entered Jewish houses. After killing four Jews in Ulič, they arrived in Kolbasov and stepped into the house of Mandel Polák where twelve young Holocaust survivors lived together. On that night, armed men asked for something to drink and eat, raped the women and afterwards shot everybody in the house. Only one young lady coincidently survived hidden under the bed cover and later ran to the house of her cousins in a different part of the village. ${ }^{56}$

Identity of these perpetrators is still uncovered. During subsequent interrogation she - as the only eye-witness of the massacre - stated that perpetrators themselves proclaimed to be Banderas immediately after entering the house. ${ }^{57}$ Even if this scene of voluntarily revelation of the perpetrator's identity was real, it can also theoretically indicate an attempt to shift the responsibility on Banderas' troops. Moreover, it needs to be contextualised that according to the police report, the strangers in uniforms, who were not speaking Slovak language, were often automatically labelled as "fascist and Banderas." ${ }^{58}$ On the other hand, speaking for UPA commitment, both murders in Ulič and Kolbasov were realised analogically to the Banderas' strategy and the official report of the Commission for investigation of Banderas' troops in the territory of Czechoslovakia stated that these crimes were undoubtedly committed by Banderas. ${ }^{59}$ However, the concrete perpetrators were never identified nor caught.

\section{Epilogue}

This case study discussed two particular typologically different acts of collective anti-Jewish violence which occurred in the aftermath of the Holocaust in the last quarter of the year 1945. Topolčany pogrom took place in a Western Slovak city, contrary to mass murders in Ulič and Kolbasov, a

\footnotetext{
2008), 107-127.

53 VHA, f. Operace Banderovci, box 51, 124/dôv.-1946.

54 Šmigel, Banderovci na Slovensku, 109.

55 ABS, f. 307, 307-95-26.

56 Archiv vizuální historie USC Shoah Foundation, interview S S. M., IC 16956.

57 SNA, f. SPR [nespracované], 2040/46.

58 Report from Bardejov, September 13, 1945. In: SNA, f. PV-bezp., box 1, without number.

59 ABS, f. 307, 307-99-5.
} 
rural environment in the Eastern part of the country. Killings in the borderland were committed by strangers, while the events in Topoľcany were literally in the hands of the members of local majority society, who physically attacked their Jewish neighbours.

Attempts to answer the question whether the end of World War II represented victory of defeat for the Jews in Slovakia somewhat connect both analysed events - struggle for a pure life during the Holocaust was in many personal stories followed by continual hostility after coming back "home," at least their previous one. Both violent acts accelerated Jewish emigration from Slovakia. Many Jews did not remain to live in the places were those crimes were committed and moved to bigger cities or completely out of the country. Direct victims of the collective physical attacks were not the only those who decided to start a new life in the different states, such as Palestine (later Israel) or the USA. Feeling of being endangered and the fear of other similar acts of violence motivated also other members of the Jewish community to flee from Czechoslovakia.

To conclude, there are no Jewish citizens currently residing in the city of Topoľcany. Cynically speaking, the intention and goal of the participants of the Topolčany pogrom - to get rid of the Jews in the city - was achieved.

\section{SOURCES}

1. Archiv bezpečnostních složek, f. 2M.

2. Archiv bezpečnostních složek, f. 302.

3. Archiv bezpečnostních složek, f. 307.

4. Archiv vizuální historie USC Shoah Foundation.

5. Slovenský národný archív, f. Povereníctvo vnútra - prezídium.

6. Slovenský národný archív, f. Sdruženie rasovo prenasledovaných.

7. Štátny archív v Košiciach, f. Štátne zastupiteľstvo 1922-1949.

8. Štátny archív v Bratislave, f. Štátne zastupiteľstvo v Bratislave 1919-1949.

9. Štátny archív v Košiciach, pracovisko Archív Trebišov, f. Okresný národný výbor v Trebišove 1945-1948 - prezidiálne spisy.

10. Štátny archív v Prešove, f. Okresné veliteľstvo Národnej bezpečnosti Sabinov ŠAPO, špecializované pracovisko Archív Levoča, Štátne zastupiteľstvo 1922-1949.

11. Vojenský historický archív, f. Operace banderovci.

\section{BIBLIOGRAPHY}

1. Apor, Péter. "The Lost Deportations and the Lost People of Kunmadaras: A Pogrom in Hungary, 1946." Hungarian Historical Review 2, no. 3 (2013): 566-604.

2. Bauman, Zygmunt. Modernost a holokaust. Bratislava: Kalligram, 2002.

3. Bergmann, Werner. "Exclusionary Riots: Some theoretical Considerations." In Exclusionary Violence. Antisemitic Riots in Modern German History, edited by Christhardt Hoffmann, Werner Bergmann, and Helmut Walter Smith, 161-184. Michigan: University of Michigan Press, 2002.

4. Bergmann, Werner. "Pogroms." In International Handbook of Violence 
Research, edited by Wilhelm Heitmeyer and John Hagan, 351-368. Dordrecht and Boston: Kluwer Academic Publishers, 2003.

5. Bulínová, Marie, ed. Československo a Izrael v letech 1945 - 1956. Dokumenty. Brno: Ústav pro soudobé dějiny AV ČR ve spolupráci s Historickým ústavem České armády a se Státním ústředním archivem, 1993.

6. Bumová, Ivica. "Protižidovské výtržnosti v Bratislave v historickom kontexte (august 1946)." Pamät̆ národa 3 (2007): 14-29.

7. Bumová, Ivica. "Židovská komunita po roku 1945 snaha o občiansku a sociálnu rehabilitáciu." In Holokaust ako historický a morálny problém v minulosti a v súčasnosti, edited by Monika Vrzgulová and Daniela Richterová, 44-66. Bratislava: Úrad vlády Slovenskej republiky, 2008.

8. Büchler, Robert. Židovská náboženská obec v Topoľčanoch. Bratislava: Slovenské národné múzeum - Múzeum kultúry, 1996.

9. Büchler, Robert. "Reconstruction Efforts in Hostile Surroundings - Slovaks and Jews after World War II." In The Jews are Coming Back. The Return of the Jews to their Countries of Origin after WWII, edited by David Bankier, 257-276. Jerusalem: Berghahn Books, 2005.

10. Frankl, Michal, and Miloslav Szabó. Budování státu bez antisemitizmu? Násilí, diskurz lojality a vznik Československa. Prague: Nakladatelství Lidové noviny, 2016.

11. Gross, Jan T. Fear: Anti-Semitism in Poland After Auschwitz. New York: Random House, 2007.

12. Hallon, Ľudovít, Miroslav Sabol, and Anna Falisová. Vojnové škody a rekonštrukcia Slovenska 1944 - 1948. (Hospodárstvo, infraštruktúra, zdravotníctvo). Bratislava: Historický ústav SAV, 2011.

13. James, Andrea. "Zmeny v postavení židovskej komunity v okrese Topoľčany počas obdobia slovenského štátu." In Česko-slovenská historická ročenka 6, edited by Vladimír Goněc, 123-133. Brno: Masarykova univerzita v Brně a Česko-slovenská komise historiků roku, 2001.

14. Kamenec, Ivan. "Trauma holokaustu. Historický alebo morálny problém?" In Slovenská otázka dnes: výber textov z časopisu OS 1997 - 2006, edited by László Szigeti, 205-211. Bratislava: Kalligram, 2007.

15. Kamenec, Ivan. "Protižidovský pogrom v Topoľ̌anoch v septembri 1945." Studia Historica Nitriensia 8 (2000): 85-99.

16. Kelman, Herbert C. "Violence without Moral Restraint: Reflections on Dehumanization of Victims and Victimizers." Journal of Social Issues 29, no. 4 (1973): 25-61.

17. Lônčíková, Michala. "Holokaust pred súdom. Správy o deportáciách z okresu Banská Bystrica v povojnovom ludovom súdnictve." In Slovensko a nacistické koncentračné tábory, edited by Eduard Nižňanský and Michala Lônčíková, 58-91. Bratislava: Stimul, 2015.

18. Lônčíková, Michala. "Coming back home? Anti-Jewish Violence in Slovakia after the Holocaust." In "Juden unerwünscht." Anfeindungen und Auschreitungen nach dem Holocaust, edited by Wolfang Benz and Brigitte Mihok, 191-212. Berlin: Metropol-Verlag, 2016.

19. Lônčíková, Michala. "Was the antisemitic propaganda a catalyst for tensions in the Slovak-Jewish relations?" In Jews and Gentiles in Central and Eastern Central Europe during the Holocaust. History and Memory, edited 
by Hana Kubátová and Jan Lániček, 76-98. London: Routledge, 2018.

20. Mihok, Brigitte. "Judenfeindliche Ausschreitungen in Ungarn Zur Dramaturgie eines Pogroms: Kunmadaras 1946." In "Juden unerwünscht" Anfeindungen und Ausschreitungen nach dem Holocaust, edited by Wolfgang Benz and Brigitte Mihok, 163-176. Berlin: Metropol, 2016.

21. Moravská, Dorota Tabitha. "Československo." In Návraty. Poválečná rekonstrukce židovských komunit v zemích středovýchodni, jihovýchodní a východní Evropy, edited by Kateřina Králová and Hana Kubátová, 65-94. Prague: Univerzita Karlova v Praze, Nakladatelství Karolinum, 2016.

22. Nižňanský, Eduard. Holokaust na Slovensku 7: Vzťah majority a židovskej minority (náčrt problému). Bratislava: Nadácia Milana Šimečku; Zvolen: Klemo, 2005.

23. Rybářová, Petra. Antisemitizmus v Uhorsku v 80. rokoch 19. storočia. Bratislava: Spoločnosť Pro Historia, 2010.

24. Szabó, Miloslav. Od slov k činom: Slovenské národné hnutie a antisemitizmus 1875 - 1922. Bratislava: Kalligram, 2014.

25. Šišjaková, Jana. "'Prípad Topoľčany' - Protižidovský pogrom (nielen) z pohladu dobových dokumentov." Acta historica Neosoliensia 10 (2007): 232-240.

26. Šmigel̆, Michal. Banderovci na Slovensku (1945-1947). Banská Bystrica: Univerzita Mateja Bela, 2008.

27. www.centropa.org 
